\title{
Commemoration or corruption? The feast-days of Abbán, Lommán, and Ailbe
}

\author{
ELLEN GANLY
}

\begin{abstract}
A saint's feast-day represents the date of his/her death. It is recorded under a calendar date in martyrologies and saints' calendars. The meaning of a feastday is contradicted when a saint is given two feast-days in a martyrology. Why might a second feast-day be recorded for a saint? This article attempts to cast some light on the matter by examining Irish martyrological entries for three different saints: St. Abbán of Moyarney and Killabban, St. Lommán of Trim, and St. Ailbe of Emly, all believed to have lived at some point between the fifth to seventh centuries. The names of these three saints are commonly recorded under two separate calendar dates in most of the Irish martyrologies. This article will compare the different Irish martyrological sources in which their feast-days are recorded. It will also offer some consideration of other genealogical and hagiographical detail on the saints. This approach will demonstrate that the attestation of a second feast-day for each saint dates to a period no later than the eighth century. Lastly, this article argues that reasons for the attestation of a second feast-day can vary, depending on the individual cultural identities of each of the three saints.
\end{abstract}

KEYWORDS: saints, feast-day, martyrology, genealogy, hagiography, patronage

Ellen Ganly [Ellen.Ganly.2013@mumail.ie] is a doctoral candidate and Chronologicon Hibernicum (ChronHib) Research Assistant at the Department of Early Irish (Sean-Ghaeilge) at Maynooth University. Her research interests centre on the role of saints in early medieval Ireland. Her doctoral project is A study of the life and cult of St. Abbán. In 2018, she published an article in vol. 9 of the Laois Heritage Society journal entitled 'Investigating the Laois origins of an Irish saint: St. Abbán'.

North American journal of Celtic studies Vol. 4, No. 2 (Autumn 2020)

Copyright (c) 2020 by The Ohio State University 


\section{Introduction}

The Irish martyrology is the main textual genre this article aims to examine. Like hagiography, martyrologies are also important sources for the study of saints' lives and cults. Although Irish martyrologies have not caught the interest of a large number of scholars, it is, nevertheless, possible to identify some key names. Editions and translations of some Irish martyrologies completed in the nineteenth century by scholars such as Whitley Stokes, for instance, have enabled subsequent scholars such as John Hennig and Pádraig Ó Riain to make contributions to martyrological studies (Stokes 1895 \& 1905; Hennig 1989; Ó Riain 2006). For Irish martyrological sources, moreover, Ó Riain's scholarship has improved our understanding of the origins of Irish martyrological texts (2000-2001 \& 2002a). Such work has also enhanced our opportunities to study the cults of particular saints and, thus, to explore in further detail the historical and literary questions that emerge from such studies.

The matter which this article attempts to explore is the problem of reduplicated feast-days in the Irish martyrologies. Originally, martyrologies were texts to which the names of martyrs were recorded. Over a certain period of time, the names of various types of ecclesiastical figures and saints were added to these texts (ó Riain 2006: xvii). Irish matarlaig 'martyrologies' or félire 'calendars' are essentially saints' calendars, which record the names of various saints under each day of each month of the year. Subsequently, this represents the date of a saint's death, which is known as the saint's feastday. However, when a saint's full name, including patronymic, is recorded under two calendar dates, it clearly results in the same saint having two feast-days. This obscures the original meaning of a feast-day and, thus, the question arises as to how a saint ends up with more than one feast-day.

\section{Review of some scholarly interpretations}

Though there is some evidence of saints' nativities being recorded in the Irish martyrologies, it is generally unlikely that one of a saint's two feast-days represents his/her nativitas 'birth-date' unless the actual word is recorded under one of the feast-days. ${ }^{1}$ This ultimately prolongs the problem of understanding the potential origin(s) of reduplicated feast-days. Nevertheless, it has not gone entirely astray from the works of some scholars. Within a wider insular and continental context, Robert Bartlett's monograph, Why can the dead do such great things?, offers a comprehensive study on the history of sainthood. As its title suggests, much of the focus is centred on the common matters and events surrounding the death of a saint. One such event is the translatio 'translation' of saints'

\footnotetext{
1. The nativity of St. Colman Ela is recorded under 3 October in MT, which also records his death-date as 26 September; see MT 76 \& 74, respectively. The nativity of St. Columba is recorded under 7 December and his death-date is recorded under 9 June in MG; see MG 112-113 \& 234-235, respectively. Cf. the Annals of Tigernach, which record the birth-year of St. Columba as $520 \mathrm{AD}$. Corpus of the Electronic texts edition, downloadable at https://celt.ucc.ie/published/T100002A/ (accessed 18 April 2020).
} 
relics, whereby the relics or body remains of a saint were moved from one location to another (Bartlett 2013: 10-13). ${ }^{2}$ The locations to which and from which the relics were transferred, moreover, were not always of a geographical type. While there is evidence of saints' relics being translated or relocated from one church to another, translation could also unfold within the same church. ${ }^{3}$

Ó Riain also acknowledges the possibility of translatio being an underlying factor for continental saints having two feast-days, as the survival of 'documentary sources' typically clarifies if an additional feast-day commemorates the saint's translatio (1982: $155^{5}$ ). 'In Ireland however', he argues, it 'is generally impossible' to make this distinction due to 'the lack of early administrative documents' (1982: 155-156). However, there is such evidence as Irish martyrologies, in which there are some references to the date of a saint's translatio alongside the saint's death-date. ${ }^{4}$ In comparison to the continental record, there is, no doubt, an overall lack of 'documentary' evidence to prove the authenticity of translatio being a historical practise in Ireland. At the same time, literary accounts of translatio in Irish texts suggest that it could be an underlying factor for a saint bearing two or more feast-days.

Another historical matter which Ó Riain $2002 \mathrm{c}$ has discussed is that of the localisation of a saint's cult. On a more general level, he demonstrates how ecclesiastical families could diffuse a saint's cult to a place that is located near the cult of another saint (Saint 1) who was of interest to the family. If, however, the cult of an additional lesser-known saint (Saint 2), bearing the same name as Saint 1, lay within the sphere of this diffusion, this could result in the cult of Saint 2 being merged with the cult of Saint 1 over a certain period of time. Thus, both of the saint's cults (Saints 1 and 2) would eventually become identified as one cult under the kindred name of the saint that is of interest to the ecclesiastical family, that being Saint 1 . If this scenario translated into the martyrological records of the saint's names, it may be discernible from Saint 1 having two feast-days, whereby an early martyrology would record the full kindred names of Saints 1 and 2 under two separate calendar dates, but, by the time a later martyrology is produced, the kindred name of Saint 2 is changed to that of Saint 1, resulting in Saint 1 having two feast-days.

This example is one of the many ways in which the localisation of a saint's cult can have intriguing implications for the origin of a saint's two feast-days. Other matters, however, can be of a liturgical type, surrounding the traditions of martyrological recordings. The most apparent examples include the celebrations of tridua and octaves.

\footnotetext{
2. For further examples of saints' relics being translated and, in the case of St. Colum Cille, for instance, of the events surrounding the translation of relics, see Bartlett 2013: 282-295.

${ }^{3}$ An interesting example of translation taking place within the same church concerns the sixth-century Gaulish Bishop Gregory of Langres in the church of St. John at Dijon; for further details, see Thacker 2002: 55.

4. For example, MT records the feast-day of St. Máel Ruain of Tallaght as 7 July, but the translation of his relics, along with many others to Tallaght, is commemorated on 10 August; see MT 54 \& 62. Despite Ó Riain's implication of translatio not being a common practice in Ireland, he later discusses, in brief detail, Máel Ruain's feast-day, the day of his translatio, and martyrological recordings of translatio in Tallaght (2006: 77).
} 
The former is, essentially, a celebration of religious observance lasting for three days. Hence, if a saint's two feast-days were 1 January and 4 January, both calendar dates may simply reflect celebrations at the start and at the end of the saint's triduum, meaning that the saint's death (1 January) was commemorated for three days after the day of his/her actual death. ${ }^{5}$ If both of the saint's feast-days represented the celebration of an octave, this would mean that the second feast-day occurred eight days after the day of the saint's death. Thus, the second feast-day would represent the octave, which thus 'extended the special commemoration of the saint to a whole week' (Bartlett 2013: 121). Octaves are well-attested among continental saints, but also in some Irish martyrological records. ${ }^{6}$

\section{Saints Abbán, Lommán, and Ailbe}

For such reasons, the possibility of octaves and tridua being underlying factors for reduplicated feast-days merits consideration before more complex scenarios surrounding translatio and localisation. However, while some scholars have evidently given consideration to such underlying factors, the actual subject of the scenario, the saint, also requires careful consideration. While ó Riain 1982: 156 has, for instance, identified saints whose reduplicated feast-days commemorate octaves, there are also some Irish saints with reduplicated feast-days in which a comparatively larger gap lies between calendar days. For such saints, consideration would have to go beyond textual traditions such as octave recordings and tridua. Consideration of the textual profile and the cultural identity of the actual saint is also necessary. Three Irish saints with reduplicated feast-days who will be taken as case studies in this article are:

1. St. Abbán of Moyarney and Killabban

2. St. Lommán of Trim

3. St. Ailbe of Emly

Most of the Irish martyrologies record two feast-days for these three saints:

1. St. Abbán, 16 March and 27 October

2. St. Lommán, 17 February and 11 October

3. St. Ailbe, 12 September and 30 December

The three saints under consideration have different profiles and are mentioned in different kinds of sources. While St. Abbán is best known for his role as the patron saint of Moyarney in Co. Wexford and Killabban in Co. Laois and for the suspected Anglo-Nor-

\footnotetext{
${ }^{5 .}$ An interesting example of a triduum concerns the martyrs of Eigg, a small island in the Inner Hebrides. According to MT 33 \& 34, respectively, the date of their martyrdom occurred on 17 April, but their elevation is commemorated on 20 April. While 20 April almost certainly refers to their translation, it also represents an interesting example of a triduum, due to the three-day gap between both days.

${ }^{6}$. For the significance of octaves on the Continent, see Bartlett 2013: 120-122. For examples of Irish saints with two feast-days, in which the second occurs eight days after the first, see ó Riain 1982: 156.
} 
man origins of his Vita, St. Lommán is the patron saint of Trim in Co. Meath, known for his role as a bishop and nephew of St. Patrick in some Patrician hagiography. ${ }^{7}$ St. Ailbe, on the other hand, is a Munster saint known from 'The law of Ailbe', but perhaps most interestingly, for his alleged pre-Patrician origins. ${ }^{8}$

\section{Methodology. The martyrologies}

The cultural identities of these three saints are evidently different, and may reveal different historical reasons for why each of them has two feast-days in the martyrologies. A total of 15 different martyrological sources refer to these saints, some of which are of German and English origin. ${ }^{9}$ While the international sources prompt some discussion in relation to the transmission of the saints' names and cults, they will not be considered in this article, as their testimony sheds no additional light on the origins of these second feast-days. References to the three saints in these German martyrological sources ultimately derive their information from earlier Irish sources such as Félire Oengusso (ó Riain 2006: 334). Therefore, the Irish martyrologies will be the primary evidence through which the two feast-days of Abbán, Lommán, and Ailbe will be explored. The research for this study has found references to these saints in seven different Irish martyrologies, all of which originate from periods between the late eighth century and the early seventeenth centuries.

The earliest of these martyrologies is 'The martyrology of Tallaght' (MT). This martyrology is 'a breviate version of the Hieronymian Martyrology augmented with the names of Irish saints' (Follett 2006: $128^{156}$ ). ${ }^{10}$ This eighth- to ninth-century Hiberno-Latin martyrology was produced within the community of Tallaght church near Dublin (ó Riain 2006: 1). ${ }^{11}$ Two extant manuscript versions of MT are known, one of which is the Franciscan MS A 3, now housed at University College Dublin. This is a detached folio from the famous twelfth-century Book of Leinster. The other manuscript version is in the Royal

\footnotetext{
7. The main editions/translations of the hagiographical sources for these two saints are VSH 3-33 and VSHB 256-274 for St. Abbán; PTBA 128-129, 148-149, \& 166-171 for St. Lommán.

8. For St. Ailbe, see VSH 46-64, VSHB 118-131, and De Paor 1996: 227-243. For a detailed review of the pre-Patrician claim, see Sharpe 1989: 376-399.

9. On some of the German martyrological manuscripts see, for example Ó Riain 2006: 234-243. For the sources of English origin, see Procter \& Dewick 1893. Cf. Hendricks 1889: 309-348 for a historical insight into the Carthusian order during the late medieval period. The Nieuwpoort (in Flanders) origin is noteworthy in relation to a now lost martyrology which was produced in this region: Martyrologium Carthusianum Neuportense ‘Carthusian Martyrology of Nieuwpoort'. De Buck's reference to Abbán's feast-days from this martyrology gives reason to believe that the saint, and perhaps other Irish saints, were, at some point, recorded in this supposedly now lost martyrological source (1867: 271).

10. Cf. Follett 2006: 131-132 for an explanatory review of Ó Riain's and Dumville's conflicting viewpoints in relation to the precise dating and origin of MT and Fó (Ó Riain 1990: 21-22, 25, 26, \& 30-31; 1993: 4-13 \& 21; 2000-2001: 222-223; Dumville 2002: 21, 22, 37-46, \& 46-47); cf. Breatnach 1996.

${ }^{11 .}$ Cf. Ó Riain 2006: 328, where he suggests that MT was 'very probably written by Óengus' mac Óengobann, who also composed Fó.
} 
Library of Belgium in Brussels, catalogued as MS 5100-5104, which dates to 1630. Best \& Lawler's 1931 edition of MT is based on both manuscript versions.

Shortly after the composition of MT, another important Irish martyrology now known as Félire Óengusso 'The martyrology of Óengus' (Fó) was produced by Óengus of Tallaght. Fó is an Irish metrical martyrology which derives most of its entries from MT, although the metrical style of Fó does not derive from MT. FÓ is particularly important due to the large number of Irish manuscripts in which it is transmitted. ${ }^{12}$ When Stokes edited and translated FÓ in 1905, he based his edition and translation on nine of these manuscripts, excepting the sixteenth-century MS G 102 , which is now located in the National Library of Ireland in Dublin. The composition of MT and Fó resulted in later martyrologies being composed in the twelfth century, viz., the Martyrology of Gorman (discussed below) and the Martyrologies of Drummond (MDr), Turin (MTr), and Cashel (MC). These martyrologies are primary derivatives of MT/FÓ, although MT and Fó were used as separate sources. ${ }^{13}$

For instance, one martyrology, which derived mainly from MT, was composed by Máel Muire Ua Gormáin, and, thus, became known as ‘The Martyrology of Gorman' (MG) (Ó Riain 2006: xxiii \& 147; cf. Follett 2006: $130^{167}$ ). A full version of MG survives in the aforementioned Brussels manuscript, which was edited and translated by Stokes in 1895. Stokes' work shows that glosses in MG mainly give genealogical and topographical details on the saints from the martyrology (1895: L). Stokes also tells us that MG is a Middle Irish martyrology dating to around the late twelfth century and that he believed that the glosses dated to a much later period than the martyrology (1895: L). A clue to the origin of some of MG glosses can be discerned from the fact that they are also preserved in a manuscript that was produced by Ó Luinín in the fifteenth century: UCD-OFM A7. ${ }^{14}$ Only the marginal (but not the interlineal) glosses from the Brussels manuscript are of seventeenth-century origin. Therefore, while the interlineal glosses are likely to be later than the period in which MG was produced, the attestation of UCD-OFM A7 confirms that they are earlier than the period in which the Brussels manuscript was produced. While MT is the main source for MG, Fó served the same role for three twelfth-century martyrologies: MDr, MTr and MC (Ó Riain 2002b: 12, 123, \& 165). MTr does, however, share some similarities with MT, although 'a cursory glance' at MTr 'reveals that' Fó is its 'principal source' (ó Riain 2002b: 123; cf. 2002b: 124-127). ${ }^{15}$

Finally, an early seventeenth-century martyrology was produced, the Martyrologium sanctorum Hiberniae, better known as 'The Martyrology of Donegal' (MD). Compiled by Míchéal ó Cléirigh, MD ‘drew most of its entries from the Martyrology of Gorman' (ó Riain 2006: xxiii). However, MD also drew on several other of the aforementioned marty-

\footnotetext{
12. FÓ survives in 10 manuscripts; for further details, see Ó Riain 2006: 174-175.

13. Cf. Follett 2006: 117-121, who offers a lucid review of the relationship between MT and Fó and also of the historical origin and dating of FO.

14. This manuscript also lists the saints from the MG, though it does not contain the verse text of the martyrology.

15. Cf. 2002b: 1-12, 121-123, \&162-163, respectively, for details on the manuscript evidence of MDr, MTr, $\& \mathrm{MC}$.
} 
rological sources, as well as hagiographical and poetical texts (Todd, Reeves, \& O'Donovan 1864: xiii-xx). MD now survives in three different manuscripts, two of which are seventeenth-century Brussels manuscripts: MS 4639 (505) and MS 5095-5096 (506). The third manuscript copy, located in the National Library of Ireland in Dublin and catalogued as MS G 27, also dates from the seventeenth century. Todd \& Reeves edited (and O'Donovan later translated into English) the MS 5095-5096 version of MD, which was then published in 1864. Since MD is a completist effort to bring in all martyrological material, the MD entries for St. Abbán, St. Lommán, and St. Ailbe can, thus, be read as later copies of the earlier martyrologies. For instance, Stokes' reference to how 'the genealogical and topographical glosses' of MG 'have been transferred to the MD' is a reflection of the various sources which MD drew upon (1895, L).

\section{The feast-days of Abbán, Lommán, and Ailbe}

In light of this brief study of the Irish martyrologies, this article will firstly compare MT, MG, and MD records of the saints' feast-days due to the three distinct periods from which these martyrologies originate, which will then be compared to FÓ, MDr, MTr, and MC records. ${ }^{16}$ Throughout this analysis, consideration will also be given to other textual evidence for the cults of these three saints. Beginning with Abbán, we find the martyrological entries for this saint are relatively abundant (see Table 1).

Table 1.

\begin{tabular}{|c|c|c|c|c|c|}
\hline \multicolumn{2}{|c|}{ THE MARTYROLOGY OF TALLAGHT } & \multicolumn{2}{|c|}{ THE MARTYROLOGY OF GORMAN } & \multicolumn{2}{|l|}{ THE MARTYROLOGY OF DONEGAL } \\
\hline 16 Mar. & 27 Oct. & 16 Mar. & 27 Oct. & 16 Mar. & 27 Oct. \\
\hline $\begin{array}{l}\text { - Abbani } \\
\text { m.h. (moccu) } \\
\text { Chormaic. }\end{array}$ & $\begin{array}{l}\text { - Abbain } \\
\text { m.h. (moccu) } \\
\text { Chormaic. }\end{array}$ & $\begin{array}{l}\text { - Abbán glosses: } \\
\text { (great-grandson of } \\
\text { Cormac, in Mag Arnaide } \\
\text { in Húi Cennselaig and } \\
\text { in Cell Abbáin in Húi } \\
\text { Muiredaig). }\end{array}$ & $\begin{array}{l}\text { - Abbán glosses: (Abbán } \\
\text { great-grandson of Cormac, } \\
\text { in Mag Arnaide in Húi } \\
\text { Cennselaig and in Cell Ab- } \\
\text { báin in Húi Muredaig). }\end{array}$ & $\begin{array}{l}\text { - Abbán, Mac Ua Corbmaic, of } \\
\text { Magh Arnaide in Ui-Ceinnsealaigh, } \\
\text { in Leinster; and of Cill Abbain in } \\
\text { Ui-Muireadhaigh in Leinster. He } \\
\text { was of the race of Labhraidh Lorc, } \\
\text { son of Ugainè Mór. Miolla, sister } \\
\text { to Bishop Iobhar, was his mother, } \\
\text { as his own life states in the first } \\
\text { chapter. [There is a Machaire-Ar- } \\
\text { naidhe in Oirghialla, in the diocese } \\
\text { of Ardmacha, in the county of } \\
\text { Muineachan.] }\end{array}$ & \\
\hline
\end{tabular}

At first glance, one may observe how MG and MD provide more detail on Abbán's patron and genealogical identity than MT. MT does, nevertheless, record the saint's full pat-

16. When referring to the date of a martyrology, I will refer to the date of its text and not the manuscript(s) in which the martyrological text is preserved. 
ronymic under both calendar dates. This demonstrates that Abbán's reduplicated feastdays originate (at least) as far back as the period in which MT was composed, namely, the late eighth or early ninth century (Follett 2006: 131-132; Ó Riain 2006: xxiii). The kindred name which both calendar dates record for the saint, moreover, is particularly noteworthy in relation to Abbán's possible cultural connection with Knapdale in Scotland. Evidence for this potential connection is of a toponymic type and is attested in different types of vernacular medieval sources dating from the thirteenth century right up to the eighteenth. ${ }^{17}$ This connection has been studied in detail by Mac Lean, who shows that two Knapdale parishes now called 'Keills' and 'Éilean Mór' were referred to (in various orthographical spellings) by Abbán's kindred name, Mac Cormaig. Assuming that Mac Cormaig represents the identity of a saint, Mac Lean 1983: 49-65 discusses the possibility of St. Mac Cormaig being Abbán. However, he also acknowledges another possibility of Mac Cormaig being an Irish saint of Clonmacnoise in Co. Offaly named Báetán Moccu Chormaic (1983: 54). Ultimately, the identity of the so-called Mac Cormaig of Keills and Éilean Mór cannot be confirmed. Nevertheless, the apparent uncertainty surrounding his identity indicates that Abbán was potentially confused with various saints of the designation Mac Cormaig. The reference to moccu Chormaic from Abbán's two feast-days in MT could originally have represented the feast-days of two different saints bearing this name.

While the name Abbán is less commonly attested as a personal name in the Irish record, the frequent appearance of the name throughout MT implies that it may not always refer to Abbán of Moyarney and Killabban. As an Irish name, Abán/Abbán can be interpreted as 'the little abbot'. ${ }^{18}$ However, because MT draws on the continental Hieronymian Martyrology as a base text, the names of continental figures are also recorded in MT. In their edition of the martyrology, Best \& Lawlor list the continental, insular, and Biblical names of the Roman Calendar separately from those of the Irish. In the Roman Calendar, the name Abbani is recorded under 2 January (MT 4). Although identical to the Latin form of 'Abbán', it is unlikely to be referring to Abbán of Moyarney and Killabban; initially, because the name derives from the Roman Calendar of the MT, but more specifically because Abbani, as Best \& Lawlor discovered, 'is an error for abbatis' (gen. sg. For 'abbot'), which was meant to be applied to the name macari. Thus, Abbani = abbatis would have occurred after macari (1931: 132). Hence, the Abbani under 2 January seems to be a ghost-like or invented figure created by an error in textual transmission.

Elsewhere, MT appears to have recorded the Irish genitive case of the saint's name under 24 August as Abbain (MT 65). This name also appears under the same calendar date in MG, which spells the name in the nominative as Abbán (MG 162-163). It is difficult to determine whether MG or the later glossator of MG identified 'Abbán' as St. Abbán of Moyarney and Killabban, as no further ancestral details are given. In MT, moreover, the fact that the name does not derive from the Roman Calendar could suggest that it rep-

\footnotetext{
17. For more details on these sources, see Mac Lean 1983: 49-65. Detail on these sources can also be found through 'Saints in Scottish place-names https://saintsplaces.gla.ac.uk/about.php (accessed 18 April 2020).

18. $A b=A b, A p$ is a $t$-stem masc. noun; see eDIL at www.dil.ie/3853 (accessed 19 March 2020). The -án element of the saint's name can be taken as the diminutive, which would translate into 'little abbot'; cf. Russell 2001: 238-239 and ó Riain 2011: 51.
} 
resents a different, but comparatively lesser known, Irish St. Abbán, particularly since 'Abbán' is not recorded under 24 August in MD, FÓ, or its derivatives (MDr, MTr, \& MC). On the other hand, the fact that these five martyrologies are not primary derivatives of continental sources could suggest that Abbain originally represented the name of a (perhaps lesser known) continental figure from the Roman Calendar of MT that founds its way into the Irish Calendar. Hence, identifying Abbain as an Irish saint may have been a scribal error and misassumption originating from the time in which MT was produced, which was later copied into MG, a primary derivative of MT.

Moreover, coming back to Abbán's two better-known feast-days, 16 March and 27 October, we find that MD mentions only the first of these feast-days. Since MD is a late and, arguably, secondary martyrology, the absence of Abbán's October feast-day possibly reflects an oversight by its compiler, Mícheál ó cléirigh, particularly since ó Cléirigh also used several other texts as sources (Todd, Reeves, \& O'Donovan 1864: xiii-Xx). In addition, the fact that ó Cléirigh refers to a place-name in Co. Monaghan that is orthographically akin to Moyarney would suggest that he was not entirely familiar with Abbán in the first place (MD 78-79). Alternatively, Ó Cléirigh was not concerned with Moyarney when recording the name of a Monaghan place-name, and could simply have been finding a relevant place in the martyrology to record additional knowledge of his own.

Whatever the intentions of ó Cléirigh, we must remember that he was attempting to produce a contemporary Irish martyrology; that, in itself, was already quite the task to have to hand. He can be forgiven for overlooking a second feast-day of a saint whose cult did not extend anywhere near Donegal, and, thus, of whom ó Cléirigh had limited knowledge (Follett 2006: 113). ${ }^{19}$ Therefore, it would be invalid to suggest that 27 October was not the saint's original feast-day, as the suggestion would only be based on the compilation of a later secondary martyrology. The fact that the October feast-day is attested in the earlier entries from MT and MG, and, as we are now about to see, all of the martyrological entries from Fó and its primary derivatives, prevents one from assuming that the October feast-day bore less significance than the other (see Table 2). ${ }^{20}$ Only MC neglects to mention Abbán's feast-day on 16 March. While I suggested that the absence of Abbán's October feast-day from MD reflects an oversight on behalf of the compiler, this theory is less applicable to the circumstance surrounding the production of MC. Abbán's March feast-day may originally have existed in MC at one point; but due to the fragmentary appearance of the manuscript in which the martyrology is preserved and, thus, its overall lack of references to many saints, the folio on which Abbán's March feast-day was recorded may not have survived (ó Riain 2002b: 162-168).

Nevertheless, Abbán's two feast-days are recorded in Fó, MDr, \& MTr. In relation to Fó, one may note how its commentary states that 27 October is 'the feast of his nativity'

19. Follett presents a map which pinpoints the various places which Míchéal ó Cléirigh visited from 1627 to 1629. It was, perhaps, in these places where ó Cléirigh gathered detail on local saints from different texts. No place in Wexford or Laois features in this map, which perhaps may clarify the possibility of ó Cléirigh knowing little about Abbán.

20. For FÓ entries and commentaries on Abbán's March and October feast-days, see Fó 1905: 82, 99, 219, \& 229. For the entries from MDr, MTr, \& MC, see: Ó Riain 2002b: 47, 103, 140, 161, \& 182. 
172 North American journal of Celtic studies

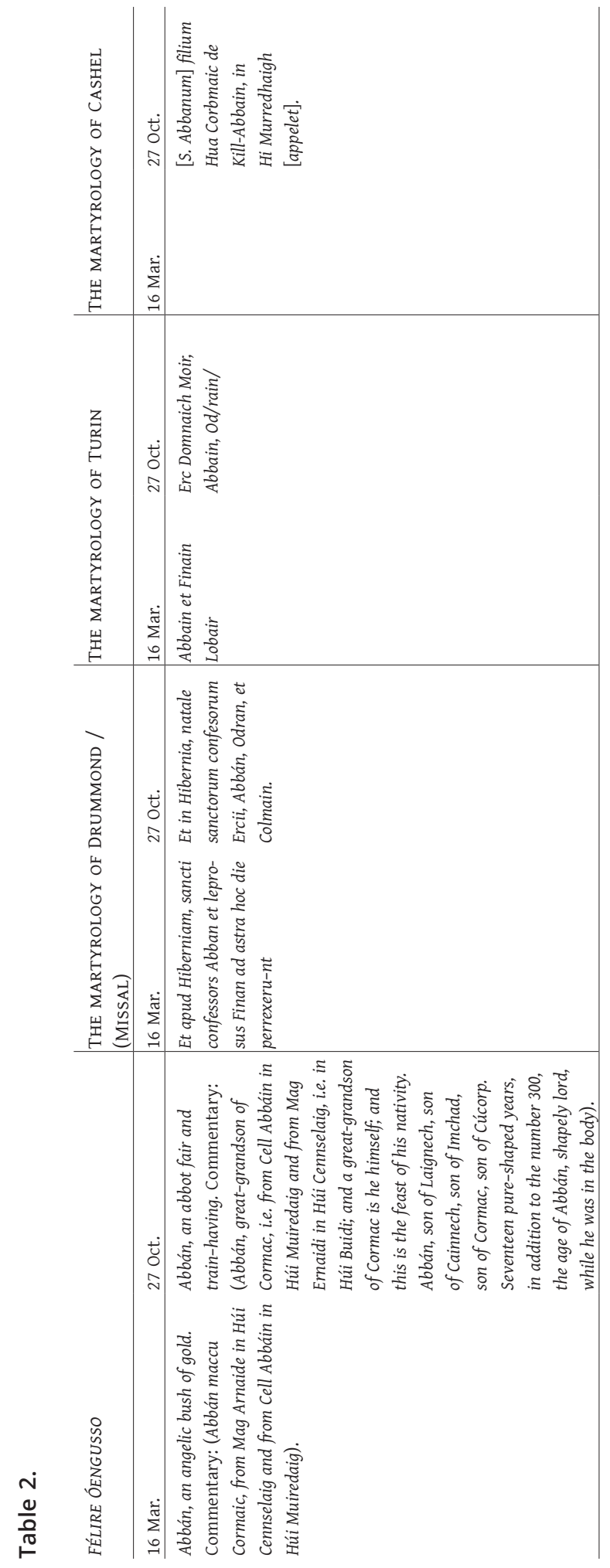


(FÓ 228-229). ${ }^{21}$ While initially implying that this is Abbán's birth-date, a sentence from the end of the saint's Vita describes this date as the day when Abbán died and went to Heaven (VSH 33). Hence, the word 'nativity' is being used to refer to Abbán's birth into a new life in Heaven. This is quite a standard practice, meaning that it is unlikely to cast any light on why Abbán has two feast-days. Moreover, Fó commentary offers further detail on Abbán's ancestry and alleged lifetime, which corresponds to two genealogical entries from the major recension of saints' genealogies in the Book of Leinster, the Book of Ballymote, the Book of Lecan, Leabhar Breac, and Rawlinson B502.22

Table 2.1.

\begin{tabular}{|c|c|}
\hline THE MAJOR RECENSION ${ }^{23}$ & FÉLIRE ÓENGUSSO COMMENTARY \\
\hline $\begin{array}{l}\text { 287.1: Abbain Maige Arnaide ocus Cilli Abbain m. Lagnig m. } \\
\text { Cainnig m. Labrada m. Cormaic m. Con Corbb. }\end{array}$ & $\begin{array}{l}\text { Aban mac Laignig meic Cainnig meic Imchada meic Cormaic meir } \\
\text { Concorp. }\end{array}$ \\
\hline $\begin{array}{l}\text { 287.4: Secht ṁbliadna delb[gla]ma déc, i fulliud armi tri chét. } \\
\text { [saegul Abb]ain delbda duind, airet robui } i \text { coluind. }\end{array}$ & $\begin{array}{l}\text { Sect mbliadna delbglana déc i fuilled airme tri cét Seagal Abain } \\
\text { delbda duinn airet ro bói i coluinn }\end{array}$ \\
\hline
\end{tabular}

These genealogical entries also envisage Abbán's mother as 'Mella, sister of St. Kevin of Glendalough'. However, this ancestral detail contradicts the hagiographical detail on Abbán's ancestry. Abbán's hagiography depicts St. Íbar of Beggerin Island in Co. Wexford as Abbán's maternal uncle (VSH 4-5; VSHB 256-257). The fact that both St. Kevin and St. Íbar are patron saints of places located in north and south Leinster, and also lie in close proximity to Killabban and Moyarney, is striking. Arguably, St. Kevin and St. Íbar could be perceived as allegorical symbols for Abbán's north and south Leinster patronage, which may further suggest that both saints may embody two opposing geographical interests in Abbán. ${ }^{24}$

A similar type of suspicion appears to be encoded into the hagiographical scenes pertaining to Abbán's death. The scenes occur towards the end of the saint's Vita, and they are centred on a serious dispute between the communities of Moyarney and Killabban, both of which wish to keep the relics of Abbán. The tension is eventually resolved by two oxen, which are attached to a cart carrying Abbán's body. The oxen resolve this tension by miraculously forming a duplicate, resulting in the presence of two bodies of Abbán, one of which went to the community of Killabban, whilst the other went to Moyarney. Subsequently, Abbán became the patron saint of both communities..$^{25}$ Oxen feature prominently in Irish hagiography and depictions of these animals determining the loca-

\footnotetext{
21. For a read on some recent research on the commentary of FÓ, see, for example, Stam 2018.

22. For the 'major recension', see Ó Riain 1985: 46-47. For Fó commentary, see Stokes 1905: 228-229.

23. These entries also depict Abbán's mother as Mella and his maternal uncle as St. Kevin of Glendalough. Abbán's maternal ancestry will be the next point of discussion.

24. For a further read on this matter, but also a discussion on some of the geographical locations mentioned in Vita Sancti Abbani and the Vita's potential origins, see Mac Shamhráin 2013: 333-338.

25. This is a very brief summary of the death scene. For the full Latin text of these scenes, see VSH 30-33.
} 
tion of a saint's body is a common trope. ${ }^{26}$ Despite its frequency, De Buck interpreted the trope in Abbán's Vita as an attempt by the hagiographical author to merge two original biographies of two different Abbáns into one (1867: 270-276):

1. An earlier lesser known Pre-Patrician Abbán of Killabban

2. A later, but more famous Abbán of Moyarney

As with the earlier example I gave in relation to localisation, De Buck's suggestion would explain why there are now two feast-days for Abbán. ${ }^{27}$ However, due to the time in which De Buck was writing, some may argue that he presents outdated ideologies on hagiography, and if one considers the overall developments in hagiographical scholarship since then, this may be so (see, for example Herbert 1996: 79-90). ${ }^{28}$ De Buck was writing during a time when hagiography was believed to be a genuine historical account of the life of a monastic saint. Hence, while Abbán's death would now be identified as a literary story, De Buck would have interpreted it as a relic of a real situation. This is arguably an underlying reason for why later contemporary scholars such as Plummer and Heist rejected De Buck's theory of the original existence of two different saints named Abbán (Plummer 1910: xxv; Heist 1976: 77).

In light of such scholarly progress, his theory, nevertheless, remains a fitting answer for Abbán's reduplicated feast-days. Perhaps two original Vitae of Abbán did survive and the death scenes were the works of an invented or borrowed literary technique to conceal this matter. ${ }^{29}$ An alternative possibility for how Abbán's death resulted in him receiving two feast-days could derive from the already discussed matter of translatio. Though the affair is more commonly associated with continental saints, we must note that translatio occurred due to medieval societal ideologies on the value of relics. When a local saint died, the communities were eager to keep his/her relics nearby, as the relics were perceived as gateways through which they could connect with the saint in Heaven. ${ }^{30}$

Wycherley's monograph highlights the value of saints' relics in early medieval Ireland. In relation to translatio, moreover (an affair that appears to be carried out by the community of Killabban in Abbán's Vita), she notes how the 'transferring of relics from one place to another (whether legally or not) actually authenticated their worth and holiness' (2015: 76). This could possibly have been the case for Abbán; but even if it was true that Abbán's relics were stolen and translated from Moyarney to Killabban, then how does it result in the saint receiving a second feast-day? Since Abbán's Vita says that he

\footnotetext{
26. One of the earliest Irish examples of this trope occurs in Muirchú's Life of St. Patrick, where untamed oxen resolve the tension over the relics of St. Patrick (see PRBA 120-123). Oxen are depicted in a similar manner in the Life of St. Molua in VSH 224.

27. See the 'Review of some scholarly interpretations' section of this article.

28. Cf. Herbert 1996: 79-90 and Sharpe 1991: 73-74 for further discussion of De Buck's work.

29. For examples of other similar stories, centred on disputed relics, see the aforementioned Muirchú's Life of Patrick in PTBA 120-123; cf. the Welsh St. Teilo, who ended up with three bodies in Vita Sancti Teliavi (LL 116-117); cf. Henken 1987.

30. For an interesting read on the societal value of saints within a broader continental context, see Brown 1981.
} 
went to heaven on 27 October, whilst mentioning nothing about 16 March, I would suspect that 27 October represents Abbán's death and burial in Moyarney, but, at some later point around 16 March, his relics were translated to the church of Killabban, resulting in the emergence of the March feast-day.

Coincidental examples from Abbán's Vita indicate that his reduplicated feast-days commemorate (at least to some degree) translatio. However, when a saint with two feastdays is known from a smaller quantity of textual material, and the martyrological attestation of the saint's two feast-days is comparatively less, it becomes more challenging to discern the potential origin(s). For Lommán of Trim, whose two feast-days are 17 February and 11 October, we see that both are only mentioned in MT (see Table 3).

Table 3.

\begin{tabular}{|c|c|c|c|c|c|}
\hline \multicolumn{2}{|l|}{ THE MARTYROLOGY OF TALLAGHT } & \multicolumn{2}{|c|}{ THE MARTYROLOGY OF GORMAN } & \multicolumn{2}{|c|}{ THE MARTYROLOGY OF DONEGAL } \\
\hline 17 Feb. & 11 Oct. & 17 Feb. & 11 Oct. & 17 Feb. & 11 Oct. \\
\hline $\begin{array}{l}\text { Loman i nAth Truim ('in Áth } \\
\text { Truim' also Oct. 11) cum sociis .i. } \\
\text { Patricii hostiari. Lurech mac Cua- } \\
\text { nach. Fortchern ocus Coel Ochtra. } \\
\text { Aeda. Aeda. Aeda. Cormacci epis- } \\
\text { copi. Conani. Cumeane episcopi et } \\
\text { Lacteani sacerdotis. Ossani, ocus } \\
\text { Sarani. Conaill. Colmani et Lactani } \\
\text { episcopi. Finnsigi uirginis. Hi } \\
\text { omnes in Áth Truim requiescunt. }\end{array}$ & $\begin{array}{l}\text { Lomman i nAth Truim } \\
\text { (in Áth Truim. Also Feb. } \\
\text { 17.) cum suis omnibus et } \\
\text { Fortcern. }\end{array}$ & & $\begin{array}{l}\text { Lommán } \\
\text { Glosses: (Lommán, a bishop, } \\
\text { another disciple of Patrick, } \\
\text { and from Áth Truim was he } \\
\text { also). }\end{array}$ & & $\begin{array}{l}\text { Lomman, Bishop, another } \\
\text { disciple of Patrick and he } \\
\text { was of Ath-Truim also; and } \\
\text { Darerca, sister of Patrick, } \\
\text { was his mother. }\end{array}$ \\
\hline
\end{tabular}

In further contrast to Abbán, the Irish martyrologies suggest that there were several individuals named Lommán. ${ }^{31}$ Nevertheless, Lommán's association with Trim under the February and October feast-days implies that MT is referring to the same Lommán. MT provides a similar, but briefer reference to Lommán under the October feast-day. This may indicate that, by the time the compiler of MT was recording the name 'Lommán' under 11 October, he knew that he was referring to the same Lommán, whose name he had already recorded under 17 February. Thus, the compiler of MT may have felt that it was unnecessary to re-list the names of Lommán's allies (from 17 February) under the October feast-day. ${ }^{32}$ Furthermore, the connection with St. Patrick may provide some explanatory insight into Lommán's reduplicated feast-days. The entry under 17 February, for instance, depicts Lommán as Patrick’s hostiari ‘door-keeper’, suggesting that Lommán

\footnotetext{
31. For a detailed discussion on Irish martyrological and genealogical entries to the name Lommán, see Plumb 2016: 112-120.

32. This is particularly demonstrable where the Latin prepositional phrase cum sociis under 17 February is changed to cum suis omnibus under 11 October (MT 17 \& 78, respectively).
} 
was a loyal disciple of Patrick. To discern the extent of this Patrician origin in the cult of Lommán, however, we must turn to some conflicting genealogical detail.33

Ó Riain's Corpus genealogiarum sanctorum Hiberniae identifies eight separate pedigrees for the name Lommán, three of which refer to a 'Lommán of Loch Uair, son of Earnain', in which the pedigree mentions nothing about a connection with Patrick (CGSH 5, 76, \& 81). This would suggest that Lommán of Loch Uair and Lommán of Trim were different saints. The other five pedigrees, however, reveal some confusion about Lommán of Trim. One of these pedigrees is attested in the 'miscellaneous items' of the hagiographical section of the Book of Leinster and the Book of Uí Mhaine, which provide the following detail on Lommán of Trim (CGSH: 128):

Table 3.1.

Miscellaneous items from the Book of Leinster (BL) and the Book Uí Mhaine (BuíM)

'Lomman Átha Truim' m. Dallain m. Bresail m. Mane m. Domnaill m. Colla Mind m. Echach Domlen.

Despite Patrick's association with Lommán of Trim under the February and October feast-days in MT, Patrick is evidently not mentioned in this pedigree of Lommán of Trim. However, because MT refers only to Lommán's ecclesiastical status, this pedigree could be interpreted as supplementary evidence for Lommán's overall identity. Nevertheless, due to the historical corruption of Irish genealogies more generally, one cannot bank on the factual reliability of this pedigree, particularly since a similar pedigree is recorded for a 'Lommán of Loch Gill' in the Book of Lecan (CGSH 55)::34

Table 3.2.

Additions from the other manuscripts in the Book of Lecan

'Loman Lacha Gili' m. Dallan m. Bresail m. Maine m. Domnaill m. Echach m. Fiachach m. Cairpre Lifechair m. Cormaic m. Airt m. Cuind Cetchathaig

The fact that the first four paternal names of Lommán of Trim and Lommán of Lough Gill match would suggest, as it does to ó Riain 2011: 401, that they are the same saint. ${ }^{35}$ Lommán of Trim's association with Patrick in MT, however, must be considered. As Ó Riain further notes, Lommán of Trim is depicted as Patrick's nephew in some wellknown hagiographical texts such as 'Tírechán's sdditamenta' and the 'Tripartite life' (2011: 401). Hence, at this point, we have three different textual genres to consider for the origin(s) of Lommán's reduplicated feast-days:

\footnotetext{
33. References to genealogies will derive from CGSH.

34. For a similar pedigree (Loman mac Dallain) attested in the metrical recension of the Book of Leinster, the Book of Ballymote, and the Book of Lecan, cf. CGSH 90. This pedigree refers neither to Trim nor Lough Gill.

35. Cf. Plumb 2016: 114, who compares these two pedigrees and also assesses the textual evidence for Darerca's familial connection with Lommán, son of Dállan.
} 

1. Genealogies ${ }^{36}$
2. Martyrologies
3. The Patrician dossier

Lommán's episcopal, but also familial, connection with Patrick is supported by the latter two textual genres, whilst the idea of Lommán being a son of 'Dállán' is only supported by the genealogical evidence. But even this paternal detail is contradicted by another genealogical entry from a category of genealogies 'On the mothers of Irish saints'. According to ó Muraíle's interpretation of women in saints' genealogies, they 'feature only incidentally', in which cases, they are usually depicted as 'mothers' (2003: 11). In this entry, Lommán of Trim is depicted as a son of Darerca, who is a sister of Patrick (CGSH 172; Ó Riain 2011: 401):

Table 3.3. ${ }^{37}$

The mothers of Irish saints from the Book of Leinster (footnote 37 here)

Darerca siur Patric mathair cóic n-epscop ṅdéc ocus da óg; Epscop Mél, Epscop Melcon, Epscop, Epscop Munis, Rioc Insi Bó Finni, Crummaine Lecna, Midnu, Mogenóc, 'Lomman Atha Truim', Luran Duanaire o Daire Lurain et Loorn o Chill Chunnu andís, Ciaran, Carantot, Epscop Coluimb, Brenaind Fine, Epscop Mac Caille, Brocan ocus Broccaid. Eiche ocus Lallóc o Śenlus iar ṁBadbgnu na di chaillig.

This entry appears to be an attempt to promote Lommán's connection with Patrick. Both the genealogical entry and the Patrician texts suggest that he is 'of British descent' (Ó Riain 2011: 401²). By combining the episcopal and familial connection with Patrick into one, this genealogist managed to promote a Patrician identity for Lommán of Trim, and may have derived much of his material from the Patrician dossier. Subsequently, this may have diminished what was, perhaps, the older identity of Lommán of Trim; potentially Lommán son of Dállán. Hence, Darerca (the envisaged mother of Lommán of Trim) is an agent for tying in the familial connection between Lommán and Patrick. Since the October feast-day is mentioned in the martyrological entries from MT, MG, \& MD, this feast-day may belong to Lommán son of Darerca, the nephew of Patrick, who was also of British descent. ${ }^{38}$ Thus, the lesser attested feast-day (17 February) was possibly associated with the lesser known Lommán (son of Dállán), and because his cult was comparatively less famous, this potentially resulted in the later diminishment of his cult.

At the same time however, one ought to take note of the fact that Dállán was associated with a location that was central for the diffusion of Patrick's cult, namely, Armagh (Ó Riain 2011: 401ํํ). Thus, the origin of Lommán's two feast-days may not solely have

\footnotetext{
36. When compilers were producing new contemporary copies of sixth- to seventh-century genealogies, 'they must accommodate later generations and must reflect the rise and, more subtly, the fall of dynasties and the lineages within them. New material tends to be added at the beginning of the (genealogical) tract and gradually older texts are pushed to the back and drastically abbreviated or may cease to be copied', an important point to consider when assessing genealogies more generally (ó Corráin 2017: 989).

37. This genealogical entry is also attested in the Book of Ballymote, the Book of Lecan, the Book of Uí Mhaine, and Laud Miscellany 610 manuscripts.

38. Lommán’s British descent is told, for instance, in Tíreachan's Additamenta (PTBA 168-169).
} 
been an attempt to promote the Patrician cult. The idea of the original existence of two different saints or cults underlying Lommán's feast-days merits additional consideration. Lommán of Trim could represent the amalgamation of two different identities:

1. Lommán mac Dállán of Armagh

2. Lommán, son of Darerca, 'one of fifteen bishop-sons of Dairearca, sister of Patrick’ (Ó Riain 2011: 401). ${ }^{39}$

However, further attempts to make this distinction are challenging, because only traces of Lommán of Trim's cult can be extracted from his dossier. More generally, one of the major obstacles we face when determining the origin of two feast-days for a lesser known saint is the probability of him/her having not had a Vita or vernacular Life. In contrast to Abbán, and as we are soon to explore with Ailbe of Emly, no Life of Lommán of Trim appears to have been composed. Hence, there are fewer clues to be found for deciding whether the Patrician cult bears any relevance to Lommán's reduplicated feastdays. In contrast to MT, MG, \& MD, no references to the February feast-day are attested in Fó and its derivatives (see Table 4). ${ }^{40}$

\section{Table 4.}

\begin{tabular}{|c|c|c|c|c|c|c|c|}
\hline \multicolumn{2}{|c|}{ FÉLIRE ÓENGUSSO } & \multicolumn{2}{|c|}{$\begin{array}{l}\text { THE MARTYROLOGY OF DRUM- } \\
\text { MOND / (MISSAL) }\end{array}$} & \multicolumn{2}{|c|}{$\begin{array}{l}\text { THE MARTYROLOGY OF } \\
\text { TURIN }\end{array}$} & \multicolumn{2}{|c|}{$\begin{array}{l}\text { THE MARTYROLO- } \\
\text { GY OF CASHEL }\end{array}$} \\
\hline $17 \mathrm{Feb}$. & 11 Oct. & 17 Feb. & 11 Oct. & 17 Feb. & 11 Oct. & 17 Feb. & 11 Oct. \\
\hline & $\begin{array}{l}\text { Lommán the scaly Commentary: } \\
\text { (Fortchern, Lommán, i.e., Fortchern son } \\
\text { of Lóeguire, son of Níall, and in Áth } \\
\text { truim he is. Or Fortchern, i.e., in Cell } \\
\text { Fortcheirn in Húi Trea are Fortchern } \\
\text { and Lommán. Of Áth truim in Bregia } \\
\text { are both of them i.e., Fortchern son of } \\
\text { Loeguire of Áth truim in Laeguire in } \\
\text { the east of Meath, and Lommán there } \\
\text { also, in Áth truim. Lommán the scaly, } \\
\text { i.e., scales of leprosy). }\end{array}$ & & $\begin{array}{l}\text { Et item, Hibernia, sanc- } \\
\text { torum confessorum Fort- } \\
\text { cheirn et Lommain }\end{array}$ & & $\begin{array}{l}\text { Cainnich, Fortcheirn, } \\
\text { Lomman }\end{array}$ & & \\
\hline
\end{tabular}

While the fragmentary appearance of MC could suggest that one of Lommán of Trim's feast-days may originally have been recorded in the martyrology, it was less likely to have been the February feast-day as it is not attested in any of these four martyrologies. However, while Fó and its derivatives yield comparatively less information for Lom-

39. Cf. Plumb 2016: 112-116 for an in-depth discussion of this identity and also the martyrological records of the different individuals named Lommán.

40. For the Fó entry and glossing, see Fó 215 \& 222-223, respectively. For the entries from MDr and MTr, see Ó Riain 2002b: 98 \& 159, respectively. No martyrological entries for either of Lommán’s feast-day(s) are attested in MC. 
mán of Trim, we must not forget the historical significance of the place from which his patronage is based: Trim. Although only briefly, Byrne comments on the dynastic status of Trim (and also Sletty). Trim is mentioned at the end of the Additamenta in the Book of Armagh. Byrne refers to some historically important aspects of the place, informing us, for instance, that the earliest annalistic reference to the church of Trim dates to the mid-eighth century, and of the claim 'that Trim was founded twenty-five years before Armagh' (1984: 317 \& 318). Incorporating a narrative of Trim into the Vita tripartita was arguably part of the attempt to develop a connection between the cults of Patrick and Lommán. Thus, envisaging Lommán as being of British descent by, for instance, giving him an ability to communicate 'in British' to 'the early Lóeguire princes' underlines this aspect of his identity (Byrne 1984: 318). ${ }^{41}$ Lommán of Trim's immersion into these Patrician texts and, thus, the political aims of the Armagh church resulted in him being identified as British. This would then have enabled the genealogist to depict Lommán (son of Darerca) as being of British descent and a nephew of Patrick (cf. Plumb 2016: 114 ${ }^{142}$ ).

As for the 'Mac Dallán' element of Lommán's name, we may now tentatively suggest that this was Lommán of Trim's Irish identity. Whether we can say that this was a different saint or simply represents a different cult of the same saint remains uncertain. In relation to the Lommán son of Darerca identity, Plumb 2016: 120 warns of the difficulty in ascertaining the British identity of Lommán of Trim, due to the 'lack of any sources' on the saint 'predating the Additamenta or MT'. Thus, one can only speculate that the entry for Lommán, the 'nephew' of Patrick, was recorded under 11 October, whilst Lommán mac Dallán's entry was recorded under the 17 February feast-day in MT.

Yet, we must remember that the Lommán under the February feast-day from MT is described as Patrick's door-keeper; thus, both the Irish and British manifestations of Lommán are linked with Patrick. In addition, Lommán mac Dállán is also linked with Armagh, which is, of course, the primary foundation for the development of Patrick's cult. Originally, there may only have been one feast-day (17 February) for one Lommán of Trim, potentially Lommán mac Dállán, whose patronymic and patronage are connected with locations (Trim and Armagh) which are historically important. Since the Lommán, 'nephew' of Patrick, individual emerges mainly from Patrician hagiography and 'the mothers of Irish saints' genealogies', his identity may simply have been a literary invention for promoting the cult of Patrick, perhaps expanding on the original 'Lommán mac Dállán' identity. This invention may have resulted in the attribution of a second feast-day (11 October) to this Lommán ('nephew' of Patrick). Thus, the October feast-day may embody a bogus Patrician saint, who subsequently became more famous than the original 'Lommán mac Dállán' due to the underlying propaganda on which this 'bogus' saint depended.

The potential origin(s) of Lommán's reduplicated feast-days is more challenging to decipher than Abbán's feast-days, particularly since there is no extant Latin or vernacular Life of Lommán. The two identities of Lommán which I have elucidated here may be a reason for the attestation of two feast-days in MT. It is also possible that Lommán's redu-

\footnotetext{
${ }^{41 .}$ Byrne also notes that an attempt 'to transfer the true patronage' (of Trim) 'from Lommán to Patrick' underlies the narrative.
} 
plicated feast-days derives from Trim's complex historical involvement with the church of Armagh and the Patrician cult. Like Lommán, St. Ailbe, son of Olchú is also the patron saint of a place that bears historical, but also ecclesiastical, importance, namely, Emly. Out of all three saints, Ailbe of Emly is the only saint whose two feast-days are attested in MT, MG, \& MD (see Table 5):42

Table 5.

Beginning with MD, we see how its entry provides the most detailed account of

\begin{tabular}{|c|c|c|c|c|c|}
\hline \multicolumn{2}{|c|}{$\begin{array}{l}\text { THE MARTYROLOGY OF } \\
\text { TALLAGHT }\end{array}$} & \multicolumn{2}{|c|}{ THE MARTYROLOGY OF GORMAN } & \multicolumn{2}{|l|}{ THE MARTYROLOGY OF DONEGAL } \\
\hline 12 Sept. & 30 Dec. & 12 Sept. & 30 Dec. & 12 Sept. & $30 \mathrm{Dec}$. \\
\hline $\begin{array}{l}\text { Ailbei eps. } \\
\text { Imlecha (of Im- } \\
\text { lech [Ibair]) }\end{array}$ & $\begin{array}{l}\text { Ailbi episcopi } \\
\text { Imlecha (of } \\
\text { Imlech) }\end{array}$ & $\begin{array}{l}\text { To the starry } \\
\text { heaven whither } \\
\text { we shall go (be- } \\
\text { longs) Ailbe of } \\
\text { Imlech Ibair }\end{array}$ & $\begin{array}{l}\text { Ailbe against battle } \\
\text { Glosses: (Ailbi epis- } \\
\text { copi Imlecha, Mart. } \\
\text { Taml. Ailbe, Elbi, Fél. } \\
\text { Oeng.) }\end{array}$ & $\begin{array}{l}\text { Ailbhe, Archbishop, of Imleach Iobhair, } \\
\text { in Munster, A.D. 541, when he resigned } \\
\text { his spirit. Ailbhe was of the race of } \\
\text { Fert-lachtga, son of Fergus, son of Ross, son } \\
\text { of Rudhraighe. Sant was the name of his } \\
\text { mother. It was he that composed in verse } \\
\text { the rule which begins, 'Say for me [to the } \\
\text { son of Saran].' } \\
\text { 'Ailbhe loved hospitality; } \\
\text { He was not a false devotee; } \\
\text { There came not into a body of clay, } \\
\text { One more generous of food or raiment.' }\end{array}$ & $\begin{array}{l}\text { Eilbhe. }{ }^{*} \text { Marianus }{ }^{*}\left({ }^{*} \text { this }\right. \\
\text { entry is in the more recent } \\
\text { hand }[R \text {-notes contributed by } \\
\text { Dr. Reeves }])\end{array}$ \\
\hline
\end{tabular}

Ailbe. However, as the textual history of MD would suggest, this is because it derives most of its material from various different types of sources (Todd, Reeves, \& O'Donovan 1864: xiii-xx). Moreover, the fact that the MD entry provides more detail for Ailbe than it does for St. Abbán and St. Lommán is most likely because Ailbe is a more famous saint. Ailbe of Emly is perhaps most famous for his alleged pre-Patrician origin, which suggests that Ailbe was active in Ireland before Patrick. However, scholars such as Sharpe have argued that there is no firm existence for pre-Patrician saints. Sharpe comes to the conclusion that textual records of the pre-Patrician matters derived 'from the compiler' of Vitae sanctorum Hiberniae (1989: 396-397). Overall however, the question of the pre-Patrician saints of Ireland has remained largely under-researched..$^{43}$ Hence, it would be unwise to disregard its connection with a saint's multiple feast-days. The scholarly attention that Ailbe's feast-days has received implies that the saint's December feast-day is less wellknown than his September feast-day. For instance, Ó Riain 2011 does not mention that Ailbe has a second feast-day on 30 December, even though it is recorded in these three

\footnotetext{
42. For the MT entries, see MT 70 \& 2; for the MG entries, see MG 174-175 \& 250-251; for the MD entries, see MD 246-247 \& 350-351.

43. Cf. Ó Riain-Raedel 1998, which is the next significant secondary source after Sharpe.
} 
martyrologies. ${ }^{44}$ On another occasion however, ó Riain has referred to the attestation of a second September feast-day, that being 10 September (2006: 87):45

Table 5.1.

\begin{tabular}{lll}
\hline $\begin{array}{l}\text { THE MARTYROLOGY OF TALLAGHT } 10 \\
\text { SEPTEMBER }\end{array}$ & $\begin{array}{l}\text { THE MARTYROLOGY OF GORMAN } 10 \\
\text { SEPTEMBER }\end{array}$ & $\begin{array}{l}\text { THE MARTYROLOGY OF DONEGAL } \\
10 \text { SEPTEMBER }\end{array}$ \\
\hline Ailbi Imligh (of Imlech; $c$ c. Sep. 12 ). & Elbe & Elbe \\
\hline
\end{tabular}

Unlike the uncertainty concerning Abbán's possible third feast-day (24 August), the reference to Emly in MT essentially confirms that Ailbe of Emly is being cited under 10 September in all three martyrologies. The timeframe between both of Ailbe's September feast-days suggests the celebration of a triduum. Elsewhere, this calendar date has been incorrectly described as the feast-day of a St. Ailbe of Shancough, which lies in the 'barony of Tirerril, Co. Sligo' (ó Riain 2011: 60). Up until the early nineteenth century, this saint had been 'forgotten in his own parish', but, fortunately, 'remembered in the neighbouring parish of Kilmactranny' (Ó Riain 2002c: 291-292). The modern-day parish of Shancough now commemorates Ailbe of Shancough's feast-day on 10 September, although as the MT reference clearly shows, it is Ailbe of Emly, not Ailbe of Shancough, whose name is recorded under this calendar date (Ó Riain 2002c: 292; 2011: 60-61). CGSH: $23 \& 81$ also distinguishes these two Ailbe's with the following patronymic details: ${ }^{46}$

1. Ailbe son of Olchán / Olchú. (of Emly)

2. Ailbe, son of Ronan. (of Shancough)

For Ailbe of Emly, eight genealogical entries are known, some of which are identical to MD content. While MD states that Ailbe of Emly died in 541, Ó Cléirigh seems to have confused the death-year of Ailbe of Emly with that of Ailbe of Shancough. To take one of the earliest Irish annals as an example, the Annals of Tigernach record 532 as the year of Ailbe of Emly's death, but record 541 as the year of Ailbe of Shancough's. ${ }^{47}$ Nevertheless, while Ó Cléirigh may have confused the death years of two saints with the same name (Ailbe), a discussion of the regions with which the two saints are associated shows that ó Cléirigh's misidentification is not the only way in which the two saints could be confused or conflated.

In an article focussing on the role played by ecclesiastical families in spreading a saint's cult, Ó Riain 2002c: 292-297 considers the cult of Ailbe of Shancough. By taking note of a saint named 'Colman mac Trena' whose cult was attached to a branch called

\footnotetext{
44. Ó Riain 2006: 87 does, however, refer to the December feast-day, where he lists some Irish saints with two or more feast-days. Aside from this mention, the feast-day has not received a great deal of focus.

45. For the MT entries, see 704; for the MG entries, see MG 174-175; for MD, see MD 242-245.

46. Further genealogical entries on the former Ailbe, (son of Olcú, of Emly) are attested elsewhere; for details, see CGSH 226.

47. See Corpus of Electronic Texts Edition, downloadable at https://celt.ucc.ie/published/T100002A/ (accessed 18 April 2020); cf. ó Corráin 2017: 938-940.
} 
'Daulraide', which is derived from the Araid, a dynasty based in Munster, Ó Riain shows that a place in north Connaught located almost directly below Shancough was named after Colman mac Trena as 'Kilmactranny'. Hence, Colman mac Trena's cult extended from the Araid dynasty, where Ailbe of Emly's cult is predominantly based, up to the region where Shancough lies. Ó Riain 2002c: 291-302 argues that the connection between the regions 'was brought about by the settlement' of 'an ecclesiastical branch of the Grecraige which plainly had an interest in' Ailbe of Emly and Colman Mac Trena. ${ }^{48}$ Since another saint, also called Ailbe (of Shancough), lay within this area, Ó Riain 2002c: 301 concludes that the cults of St. Ailbe of Emly and St. Ailbe of Shancough were diffused by itinerant ecclesiastical families. This may provide some explanation for how two saints with the same name (Ailbe), whose cults' existed within the same realm of an ecclesiastical family, may have been incorrectly conflated or diffused into one over a period of time.

There are two other possible reasons for the martyrological attestation of two closely occurring September feast-days for Ailbe of Emly: on the one hand, 10 September may merely be a copying error; alternatively, during the time in which MT was produced, 12 September may have clashed with another important church event within Emly. Thus, Ailbe's 12 September feast-day was possibly moved back two days in order to avoid a clash of two important events. ${ }^{49}$ Whatever the cause(s), 10 September now survives as a feast-day of Ailbe's in MT, MG \& MD. However, the more detailed martyrological entries for Ailbe under 12 September would suggest that it was more widely recognised as Ailbe's main September feast-day. ${ }^{50}$ As for the saint's December feast-day, its attestation in Fó and its related sources would suggest that this is a secondary feast-day (see Table 6). ${ }^{51}$

Table 6.

\begin{tabular}{|c|c|c|c|c|c|}
\hline \multicolumn{2}{|l|}{ FÉLIRE ÓENGUSSO } & $\begin{array}{l}\text { THE MARTYROLOGY OF DRUM- } \\
\text { MOND / (MISSAL) }\end{array}$ & $\begin{array}{l}\text { THE MARTYROLOGY OF } \\
\text { TURIN }\end{array}$ & \multicolumn{2}{|c|}{$\begin{array}{l}\text { THE MARTYROLO- } \\
\text { GY OF CASHEL }\end{array}$} \\
\hline 12 Sept. & $30 \mathrm{Dec}$. & 12 Sept. & 12 Sept. & 12 Sept. & $30 \mathrm{Dec}$. \\
\hline $\begin{array}{l}\text { Celebrate Ailbe's feast Commen- } \\
\text { tary: (of Ailbe, i.e., from imlech } \\
\text { Ibair. Ailbe son of Olcán, son of } \\
\text { Arra, son of Dala, son of Láiter, } \\
\text { son of Imtos, son of Fertlachta, } \\
\text { son of Celtchar). }\end{array}$ & $\begin{array}{l}\text { With virginal Ailbe, we } \\
\text { shall attain his feast } \\
\text { Commentary: (Ailbe, } \\
\text { i.e. of Imbliuch Ibair). }\end{array}$ & $\begin{array}{l}\text { Item, in Hibernia, natale } \\
\text { sanctorum sacerdotum et } \\
\text { confessorum Lasren et Ailbi } \\
\text { et sanctae uirginis Fleide. }\end{array}$ & $\begin{array}{l}\text { Molasse Daminse et } \\
\text { Ailbe Imlech/a/ / } \\
\text { Ibair/. }\end{array}$ & & \\
\hline
\end{tabular}

48. The Grecraige were a tribe based in Munster, who were 'among the Corco Mruad in in north Clare and also at Beare Island in West Cork' (Byrne 2001: 67).

49. A similar example concerning the influence of churches upon the fluctuation of saints' feast-days concerns St. Finbarr of Cork, whose name is spelt in four different ways in four closely occurring September feastdays, 25 September to 28 September. For further details, see Ó Riain 1983: $21^{18}$.

50. For a brief comment on the two September feast-days, see Ó Riain 2011: 60. For his suggestion on 12 September being more important than 10 September, see 2002c: $292^{5}$.

51. For MTr, no entries in November or December can be identified 'due to a lacuna in the manuscript' (ó Riain 2002b: 161). Hence, we are unable to determine whether the MTr compiler had or had not recorded Ailbe's December feast-day. 
Evidently, the December feast-day is only mentioned in FÓ. While it is not attested in the later martyrologies, its mention in Fó merits consideration. Noting that 'we shall attain his feast' under the December calendar date, this wording may simply be a reflection of the author's poetical wording throughout the martyrology. On the other hand, however, it could also suggest that there was a particular need to record the December feast-day alongside the September feast-day, which may have emerged from another conflicting cult of Ailbe. Perhaps the most obvious conflicting cult to consider for Ailbe is his pre-Patrician identity. The term 'pre-Patrician' is associated with the saints (mainly of Munster origin) who are depicted as individuals who were active before the arrival of Patrick in Ireland. ${ }^{52}$ According to the Irish annalistic record, 432 is the year of Patrick's arrival in Ireland, at which point he is said to have baptised many of the nation's people..$^{53}$ This claim was particularly expanded by the seventh-century hagiographers Muirchú and Tírechán, which subsequently resulted in Patrick being characterised as the 'apostle' of Ireland in most of the Irish source material..$^{54}$ The subsequent implication that Ireland was not Christian before Patrick, however, is contradicted by the Chronicle of Prosper of Aquitaine, which records 431 as the year when a man named 'Palladius' was sent as the 'first bishop to the Irish believing in Christ' (Mommsen 1892: 473; cf. ó Riain-Raedel 1998: 17). Most likely, the subsequent expansion of Patrick's fame as the 'apostle' of Ireland and the inevitable expansion of his church networks throughout the country came to fruition through 'the supremacy of the church in Armagh' (ó Riain-Raedel 1998: 19). Presumably, this expanding cult of Patrick was the subject of much Irish propaganda, as his seventh-century hagiographers imply that Palladius' mission in Ireland was unsuccessful..$^{55}$

The author of Ailbe's Vita, on the other hand, attempts to promote Palladius. Most notably, a scene which depicts Ailbe receiving baptism from Palladius would have disrupted the intentions of the Church of Armagh (VSH 47; De Paor 1996: 228). For Armagh, a more ideal figure to depict as the enactor of Ailbe's baptism would most likely have been Patrick. Like the Patrician cult, however, this scene from Ailbe's Vita, being an embodiment of the pre-Patrician cult, is perhaps equally subject to propaganda from Munster ecclesiasts. Outside of hagiography, political tension between Munster and Armagh is also recognisable from the eighth-century Law of Ailbe, which was most likely produced in an attempt to respond to the power of the Armagh church, which was claimed by the earlier Law of Patrick (Ó Riain-Raedel 1998: 19). Hence, much of Ailbe's cultural identity has been made subject to matters and events centred on the pre-Patrician cult. Such subjection must have had implications for the manner in which the Irish textual record portrayed the saint.

\footnotetext{
52. There are three other saints who are depicted as pre-Patrician in the Irish textual record: St. Declan of Ardmore, St. Ciarán of Saighir, \& St. Íbar of Beggerin Island. Abbán is also 'credited with a missionary role in Ireland before St. Patrick'; see Sharpe 1991: 115-116 and cf. Ó Riain-Raedel 1998: 19.

53. See for example Chronicon Scotorum. Corpus of Electronic Texts Edition, downloadable at https://celt. ucc.ie//published/T100016A/index.html (accessed 18 April 2020).

54. See PTBA 61-192 for a read of the Patrician dossier. For some martyrological references to Patrick's role as 'the apostle of Ireland, see Fó 82, MG 56-57, \& MD 78-79.

55. A detailed review on past scholarly interpretations of the significance of Palladius alongside the textual record of Patrick is given by Sharpe 1989: 378-381.
} 
To a degree, Ailbe can be identified as a cultural symbol of Munster's ecclesiastical power, as Patrick undoubtedly symbolises the Church of Armagh. This distinction also materialises in the Vitae of St. Ailbe and St. Declan. Both Vitae expand on an episode concerning 'the conversion at Cashel of King Oengus mac Nadfroích by St. Patrick' from Tírechán's Life of Patrick (ó Riain-Raedel 1998: 19); cf. Tíreachan's Collectanea in PTBA 122-167. The Vitae of Ailbe and Declan further claim that Patrick gave Munster to Ailbe, who then became the patron saint of the province, and Ailbe was later depicted as 'the archbishop of Munster with his seat in Cashel' (Ó Riain-Raedel 1998: 19). ${ }^{56}$ The hagiographical association with Munster, but particularly a second place (alongside Emly) of 'ecclesiastical prominence' (Cashel) may have implications for the origin of Ailbe's December feast-day (Ó Riain 2011: 58). Such hagiographical claims must inevitably have reflected the development of church networks throughout Munster. It is possible that the growth of a church within the diocese of Cashel resulted in the emergence of a second feast-day for the saint. This may serve as a tentative suggestion for the origin of Ailbe's December feast-day. The fact that this feast-day is not attested in the later martyrologies drawing on Fó, could also suggest that the potential cult decreased in political power by the eleventh to twelfth centuries. Alternatively, it may simply be the result of rationalisation on the part of the compilers of the later martyrologies. On a broader scale, this would suggest that there can be an underlying hierarchy in saints- feast-days, as one was privileged over another in the course of transmission.

\section{Conclusion}

Overall, this article has attempted to show that the problem of reduplicated feast-days is a challenging one. As the latter discussion on Ailbe suggests, reduplicated feast-days can reflect the emergence of church or ecclesiastical interest or a conflict of power ownership. Considering the plausibility of four common causes of reduplicated feast-days was enabling for uncovering potential comparisons and contrasts with the cultural identities of St. Abbán, St. Lommán, and St. Ailbe. Though octaves were not attested, and, thus, unsuitable to consider for the Irish martyrological recordings of these three saints, the significance of tridua was important in relation to Ailbe's two September feast-days (10 $\& 12$ September). As I argue from the outset, localisation could unfold through the (accidental or deliberate) merging of two different saints bearing the same name, as a result of ecclesiastical families fusing and diffusing saints' cults. This could result in one of the saints' kindred names being changed to that of another saint, meaning that the one saint would be incorrectly attributed the feast-day of the other, and, thus, end up with two feast-days in later martyrologies. In relation to Ailbe of Emly and Ailbe of Shancough, localisation unfolded in a less straightforward manner, as 10 \& 12 September were recorded

\footnotetext{
56. For a read of these two Vitae, see Plummer 1910: 46-64 \& 32-59. An English translation of these Vitae is provided by De Paor 1996: 227-243 \& 244-271.
} 
as two feast-days for Ailbe of Emly in MT. The former calendar date was then incorrectly commemorated as Ailbe of Shancough's feast-day by the modern-day parish.

Hence, the problem of reduplicated feast-days alongside the diffusion of saints' cults with identical names can also result in modern-day misidentification of a saint's feastday. The fact that the seventeenth-century MD mixed up the death-dates of the two Ailbes, moreover, shows how easily such misattribution can arise, as a result of one Ailbe being a famous saint, whilst the other Ailbe is comparatively less known. The idea of the original existence of two saints with the same name is argued for the origin of Abbán's reduplicated feast-days. Like Ailbe, a possible third feast-day (24 August) was also recorded for Abbán in MT and MG. However, its lack of supplementary patronymic or genealogical details does not guarantee that the name refers to Abbán of Moyarney and Killabban. The uncertainty surrounding the origin of this third feast-day, being a patron saint of two locations and bearing possible connections with Knapdale, could all be underlying factors for the existence of one or more different saints with the same name (or patronymic as the Knapdale connections would indicate).

The connection with Knapdale could indicate that the saint was re-localised and given a new identity in an alternative locale. As for Moyarney and Killabban, however, it is also possible that both locations represent two different conflicting cults emerging from the same saint. Though the depiction of both ecclesiastical communities attempting to fight over the relics of Abbán in his Vita is evidently of a literary type, alongside the common trope of the oxen, this episode almost certainly presents in disguised form an instance of translatio from one church location to another. In general, translatio is a plausible cause of saints acquiring reduplicated feast-days; for Abbán, translatio emerges as a result of Moyarney and Killabban wanting to obtain his relics. The depiction of both communities embodying two conflicting cults can also be recognised from the fact that Abbán's Vita depicts the saint's maternal uncle as Bishop Íbar of Beggerin Island, whilst the medieval Irish genealogies depict St. Kevin of Glendalough as his uncle. Like Ailbe's connection with Munster, Íbar and Kevin could be perceived as embodiments of the regions in which Moyarney and Killabban lie. This indicates that there is underlying tension between both locations, not only in the hagiographical scenes pertaining to Abbán's death, but also throughout much of the textual record on Abbán.

Lommán of Trim's conflicting genealogical detail is also likely to be subject to much propaganda. Unlike St. Abbán and St. Ailbe, the name Lommán is more commonly attested in the Irish martyrologies. While it is relatively straightforward to distinguish between the different Lommán's in MT, for instance, the genealogies conflate some of these figures by giving them identical pedigrees. In relation to Lommán of Trim, whose name is recorded under 17 February and 11 October in MT, his identity appears to represent a potential merging of two Lommán's with different patronymic/matronymic, Lommán mac Dállan and Lommán son of Darerca. Lommán of Trim can be recognised as a Patrician saint due to his prominent association with Patrick in hagiography and, particularly, through the matronymic identity, son of Darerca, whom the Irish genealogies depict as a sister of Patrick. Like Abbán with St. Íbar and St. Kevin, the genealogies depict Patrick as 
a maternal uncle of Lommán's. However, as we have seen, the 'mac Dállán' identity also bears Patrician origins, as the name 'Dállan' is associated with Armagh.

Whether there were originally two different identities or cults (Lommán mac Dállán and Lommán son of Darerca) underlying Lommán of Trim, they both, nevertheless, appear to be inextricably linked with the cult of Patrick. In further contrast to Abbán and Ailbe, only one martyrology, MT, records two feast-days for Lommán of Trim. While this article has shown that the October feast-day evidently became more famous than the February feast-day, it is also possible that the historical and literary depictions of Lommán mac Dállán and Lommán, son of Darerca may have played a part in the subsequent popularity of the October feast-day. More broadly, this demonstrates that the attestation of two feast-days for an Irish saint could derive from many possible factors other than the original meaning of a feast-day, the day of a saint's death. Though the common factors such as translatio and localisation seem to have had some influence upon the reduplicated feast-days of Abbán and Ailbe, such factors seem comparatively less influential for the origin of Lommán's two feast-days. The most obvious suggestion, that two feast-days represents the deaths of two different saints with the same name, is always a possibility, although as I have hopefully shown in this article, it is far from the only explanation. Aside from the four common causes of reduplicated feast-days, other reasons can be identified from genealogical misrepresentations, coincidental examples from hagiographical texts, or a saint's association with controversial ecclesiastic politics. Issues such as the composition and transmission of martyrologies, their relationships with other textual genres, and the identities of the individual saints in question, demand comparative consideration in order to understand the multiple origins of reduplicated feast-days. ${ }^{57}$

\section{ABBREVIATIONS}

$\begin{array}{lll}\text { CGSH } & = & \text { Ó Riain 1985 } \\ \text { eDIL } & = & \text { http://dil.ie } \\ \text { FÓ } & = & \text { Stokes 1905 } \\ \text { LL } & = & \text { Evans \& Rhys 1893 } \\ \text { MC } & = & \text { Ó Riain 2002b: 169-184 } \\ \text { MD } & = & \text { Todd, Reeves, \& O’Donovan 1864 } \\ \text { MDr } & = & \text { Ó Riain 2002b: 25-120 } \\ \text { MG } & = & \text { Stokes 1895 } \\ \text { MT } & = & \text { Best \& Lawlor 1931 } \\ \text { MTr } & = & \text { Ó Riain 2002b: 133-161 } \\ \text { PA } & = & \text { Mommsen 1892 } \\ \text { PTBA } & = & \text { Bieler 1979 }\end{array}$

57. I would like to thank the two anonymous readers for their helpful comments and suggestions. This article was written as part of the project Chronologicon Hibernicum that has received funding from the European Research Council (ERC) under the European Union's Horizon 2020 research and innovation programme (grant agreement No. 647351). 
$\begin{array}{lll}\text { VSH } & = & \text { Plummer } 1910 \\ \text { VSHB } & = & \text { Heist } 1965\end{array}$

\section{References}

Bartlett, Robert. 2013. Why can the dead do such great things? Saints and worshippers from the martyrs to the Reformation. Princeton: Princeton University Press.

Best, Richard Irvine, \& Hugh Jackson Lawler (ed.). 1931. The Martyrology of Tallaght; from the Book of Leinster and MS. 5100-4 in the Royal Library, Brussels. London: Henry Bradshaw Society.

Bieler, Ludwig (ed. \& trans.). 1979. The Patrician texts in the Book of Armagh. Dublin: Dublin Institute for Advanced Studies.

Breatnach, Liam. 1996. Poets and poetry. In McCone \& Simms 1996: 65-77.

Brown, Peter. 1981. The cult of the saints. Its rise and function in Latin Christianity. Chicago: University of Chicago Press.

Byrne, Francis J. 1984. A note on Trim and Sletty. Peritia 3: 316-319.

- 2001. Irish kings and high kings ${ }^{2}$. Dublin: Four Courts Press.

De Buck, V. 1867. De SS. Abbanis Kill-Abbaniensi et Magharnuidhiensi Abbatibus. Hiberniae Commentarius Praevius. Acta Sanctorum Octobris, Acta Sanctorum Hiberniae quotuot urbe coluntur begun by J. Bollandus 12: 270-293.

De Paor, Liam. 1996. Saint Patrick's world. Notre Dame: University of Notre Dame Press.

Dumville, David. 2002. Félire Óengusso. Problems of dating a monument of Old Irish. Éigse 33: 19-48.

Evans, J. Gwenogvryn, \& John Rhys (eds.). 1893. The text of the Book of Llan Dâv. Oxford: J. Gwenogvryn Evans.

Follett, Westley. 2006. Céli Dé in Ireland. Monastic writing and identity in the rarly Middle Ages. Woodbridge: The Boydell Press.

Heist, William. (ed.). 1965. Vitae sanctorum Hiberniae ex codice olim Salmanticensi nunc Bruxellensi. Brussels: Société des Bollandistes.

—. 1976. Over the writer's shoulder. Saint Abban. Celtica 11: 76-84.

Hendricks, Lawrence. 1889. The London Charterhouse, its monks and its martyrs, with a short account of the English Carthusians after the dissolution. London: Charterhouse Carthusians.

Henkens, Elissa, J. 1987. Traditions of the Welsh saints. Cambridge: D. S. Brewer.

Hennig, John. 1989. Medieval Ireland, saints and martyrologies. Selected studies, ed. Michael Richter. Northampton: Variorum Reprints.

Herbert, Máire. 1996. Hagiography. In McCone \& Simms 1996: 79-91

Mac Lean, Doughlas. 1983. Knapdale dedications to a Leinster saint. Sculpture, hagiography and oral tradition. Scottish studies 27: 49-65.

Mac Shamhráin, Ailbhe. 2013. Ailbe Ua Máel Muaid, Uí Chennselaig and the Vitae Sanctorum Hiberniae. In Princes, prelates and poets in medieval Ireland. Essays in honour of Katharine Simms, ed. Seán Duffy, 309-338. Dublin: Four Courts Press.

McCone, Kim, \& Katharine Simms (eds.). 1996. Progress in medieval Irish studies. Maynooth: Department of Old Irish, St. Patrick's College.

Mommsen, Theodor (ed.) 1892. Prosper of Aquitaine, Epitoma chronicon. In Chronica minora saec. IV. V. VI. VII. 1, MGH AA9, 341-485. Berlin: Wiedman.

Ó Corráin, Donnchadh. 2017. Clavis litterarum Hibernensium. Turnhout: Brepols.

ó Muraíle, Nollaig. 2003. Leabhar mór na ngénealach. The great book of Irish genealogies. Dublin: De Búrca. 
Ó Riain, Pádraig. 1982. Towards a methodology in early Irish hagiography. Peritia 1: 146-159.

—. 1983. Cainnech alias Colum Cille, patron of Ossory. In Folia Gadelica. Essays presented by former students to R. A. Breatnach, ed. Pádraig de Brún, Seán ó Coileáin, \& Pádraig Ó Riain, 20-35. Cork: Cork University Press.

(ed.). 1985. Corpus genealogiarum sanctorum Hiberniae. Dublin: Dublin Institute for Advanced Studies.

—. 1990. The Tallaght martyrologies, redated. Cambrian medieval Celtic sStudies 20: 21-38.

- 1993. Anglo-Saxon Ireland. The evidence of the Martyrology of Tallaght. Cambridge: Dept. of Anglo-Saxon, Norse, and Celtic, University of Cambridge.

- 2000-2001. The Martyrology of Óengus. The transmission of the text. Studia Hibernica 31: 221-242.

- 2002a. A Northumbrian phase in the formation of the Hieronymian Martyrology. The evidence of the Martyrology of Tallaght. Analecta Bollandiana 120: 311-363.

- (ed.). 2002b. Four Irish martyrologies. Drummond, Turin, Cashel, York. London: Henry Bradshaw Society.

—. 2002c. Irish saints' cults and ecclesiastical families. In Thacker \& Sharpe, 291-302.

—. 2006. Feastdays of the saints. A history of Irish martyrologies. Bruxelles: Société des Bollandists.

—. 2011. A dictionary of Irish saints. Dublin: Four Courts Press.

Ó Riain-Raedel, Dagmar. 1998. The question of the ‘pre-Patrician' saints of Munster. In Early medieval Munster. Archaeology, history, and society, ed. Michael A. Monk \& John Sheehan, 17-22. Cork: Cork University Press.

Plumb, Oisín. 2016. 'Over the storm-swelled sea'. Early medieval ecclesiastical migration from northern Britain to Ireland. Ph.D. dissertation, University of Edinburgh.

Plummer, Charles (ed.). 1910. Vitae sanctorum Hiberniae; partim hactenus ineditae. Oxford: Clarendon Press.

Procter, Francis \& Dewick, E. S. (eds. \& trans.). 1893. The martiloge in Englysshe after use of the Chirche of Salisbury and as it is redde in Syon with addicyons. Printed by Wynkyn de Worde in 1526. London: Harrison and Sons.

Russell, Paul. 2001. Patterns of hypocorism in early Irish hagiography. In Studies in Irish hagiography. Saints and scholars, ed. John Carey, Máire Herbert, \& Pádraig ó Riain, 237-249. Dublin: Four Courts Press.

Sharpe, Richard. 1989. Quatuor sanctissimi episcopi. Irish saints before St. Patrick. In Sages, saints and storytellers. Celtic studies in honour of Professor James Carney, ed. Donnchadh ó Corráin, Liam Breatnach, \& Kim McCone, 376-399. Maynooth: An Sagart.

- 1991. Medieval Irish saints lives. An introduction to Vitae Sanctorum Hiberniae. Oxford: Clarendon Press.

Stam, Nike. 2018. Strategy of accident. Code-switching in the Commentary to the Félire Óengusso. In Code-switching in medieval Ireland and England. Proceedings of a workshop on code-switching in the medieval classroom, Utrecht 29th May, 2015, ed.Mícheál ó Flaithearta \& Lars B. Nooij, 71-94. Bremen: Hempen.

Stokes, Whitley (ed. \& trans.). 1895. The Martyrology of Gorman; edited from a manuscript in the Royal Library Brussels. London: Henry Bradshaw Society.

_ed. \& trans.). 1905. Félire Óengusso. The Martyrology of Oengus. London: Henry Bradshaw Society.

Thacker, Alan. 2002. The making of a local saint. In Thacker \& Sharpe 2002: 45-73.

_ \& Richard Sharpe (eds.). 2002. Local saints and local churches in the early medieval West. Oxford: Oxford University Press.

Todd, James Henthorn, \& William Reeves (eds.), \& John O’Donovan, John (trans.). 1864. The Martyrology of Donegal. A calendar of the saints of Ireland. Dublin: The Irish Archaeological and Celtic Society.

Wycherley, Niamh. 2015. The cult of relics in early medieval Ireland. Turnhout: Brepols. 